\title{
On Equalizing School Expenditures
}

\author{
Therese A. McCarTy and Harvey E. Brazer \\ Department of Economics, Social Sciences Building, Union College, Schenectady, NY 12308, U.S.A.; \\ and Department of Economics, The University of Michigan, Ann Arbor, MI 48109, U.S.A.
}

\begin{abstract}
A conflict between efficiency and equity exists in the provision of public education. We examine this conflict and consider a compromise approach to school finance, "district power equalization" (DPE). DPE has never been implemented in its "pure" form, which would require raising tax prices in wealthy districts as well as lowering them in poorer districts. We present simulations of districts' expenditure per pupil under two DPE plans in three states. We find that a "pure" DPE plan would reduce variance in expenditure among districts and have sometimes dramatic consequences for the rank ordering of districts within a state by expenditure per pupil.
\end{abstract}

\section{INTRODUCTION}

Gross inequalities among school districts in per pupil expenditures are the most common target of those seeking reform of school finance in the courts and through the legislative process. For some the issue of greater equality in levels of school outlays has been a matter of "fundamental right"' under the equal protection clauses of the U.S. and state constitutions. The U.S. Supreme Court's decision in Rodriguez, however, denied elementary and secondary education the status of a fundamental right subject to equal protection. Subsequently, equalization of per pupil expenditures has been demanded in the name of equity and as a requirement of state constitutional education clauses calling, variously, for "thorough and efficient", "general and uniform", or otherwise designated systems of public schools in the state. ${ }^{2}$

In this paper we are not primarily concerned with the legal or philosophical arguments for or against equalization. Our purpose, rather, is to cast some light on the issues associated with the policy position that accepts equalization, in greater or lesser degree, as a goal in education finance. ${ }^{3}$

We begin with a brief statement on the distribution of per pupil expenditures in the three states that are the focus of our study, Connecticut, New
Jersey, and Virginia. This is followed by an analysis of the conflict between equity and efficiency in school finance. We then consider a compromise approach, "district power equalization", which would reduce inequalities in levels of expenditure by altering the terms under which districts obtain state aid without forcing local districts to relinquish control over spending decisions or revenue policy.

Following an examination of the options available, we proceed to the design of the appropriate policy instruments, and then simulate the effects of their implementation on districts' expenditure.

\section{VARIANCE IN SCHOOL EXPENDITURES}

\section{The Data}

Our analysis focuses on data for Connecticut, New Jersey, and Virginia. These states were chosen because their school districts are coterminous with overlying units of local government for which relevant U.S. Census data are available and they are representative of three regions of the country. State aid plays a major role in education finance in each of them. Non-categorical or "basic" aid in 1982 amounted to $22 \%$ of total expenditures in Connecticut, $28 \%$ in New Jersey, and $34 \%$ in Virginia. Moreover, the tradition of substantial local fiscal autonomy continues to prevail in each of them.

[Manuscript received 11 October 1989; revision accepted for publication 13 February 1990.] 
Variance in per pupil operating expenditures for elementary and secondary education is large in these states. This is illustrated in Table 1 . The highest spending district in Virginia spent over three times as much as the lowest district, and the distsrict at the 95th percentile outspent the one at the 5th percentile by almost two to one. The coefficient of variation (SD over the mean), at 0.23 , provides a more general measure of the disparities that prevailed. Variance was less extreme in Connecticut and New Jersey, but it was certainly large enough to invoke serious concerns about both equity in and adequacy of school financing in these states.

\section{Local Autonomy and Determinants of Demand}

Apart from curriculum requirements and other constraints imposed by the state, education expenditures are subject to forces governing demand in much the same fashion as goods and services in general. Differences among school districts in levels of expenditure are attributable, for the most part, to differences among them in demand for education. If we are to reduce variance in expenditures for schools, the design of the policy instruments for doing so must begin with those factors governing demand. For this purpose we refer to our studies of the demand for education (Brazer and McCarty, 1986, 1987). The estimated equations presented there suggest that demand is a function of "tax price" 4 and income, as well as indicators of preferences such as proportion of the population of the community who are aged, who are owner occupiers, who have less than a high school education, and who voted Democratic in the most recent Presidential election (1980), and characteristics of school districts such as the size and rate of growth of public school enrollment. These results are reproduced in Appendix A.

It follows that policy instruments designed to affect demand for education must look to these variables, some of which may be directly or indirectly influenced by state policy and some of which obviously cannot be so influenced. Thus it may be possible, for example, to design a system of state aid that compensates for low income or property wealth, but not for voter preferences or the educational attainments of the adult population. Preferences, if they are to be affected, must be approached through means other than fiscal instruments, while other factors, such as the age distribution of the population, are beyond short-run influences.

\section{EQUITY AS POLICY OBJECTIVE}

\section{Defining Equity}

Equality of expenditure per pupil among school districts has been seen as a means of realizing equity for low income pupils resident in central cities and close-in suburbs. ${ }^{5}$ At issue, although not commonly discussed before the courts, is the appropriateness of this definition of equity. Equality in per pupil expenditures is neither necessarily equitable nor acceptable as a policy objective. We turn now to alternative definitions of equity in education, and examine the relationship of each to the goal of equal expenditure per pupil. ${ }^{6}$

Equality in educational achievement defines equity in its most demanding form, one which the school system alone should not even be encouraged to seek, for to do so would entail unimaginably high costs. Its attainment would require some means of restraining higher achieving pupils, a prospect that

Table 1. Education expenditure per pupil 1981-1982

\begin{tabular}{|c|c|c|c|c|}
\hline & Minimum & 5th percentile & 95th percentile & Maximum \\
\hline $\begin{array}{l}\text { Connecticut } \\
\text { New Jersey } \\
\text { Virginia }\end{array}$ & $\begin{array}{l}1841.0 \\
1779.7 \\
1397.4\end{array}$ & $\begin{array}{l}1940.0 \\
2086.8 \\
1632.3\end{array}$ & $\begin{array}{l}3532.0 \\
3638.4 \\
2938.9\end{array}$ & $\begin{array}{l}3761.0 \\
4873.3 \\
4331.7\end{array}$ \\
\hline & $\begin{array}{c}\text { Mean } \\
\text { (dollars) }\end{array}$ & Coefficient of variation & $\frac{\text { Maximum }}{\text { Minimum }}$ & $\frac{95 \text { th percentile }}{\text { 5th percentile }}$ \\
\hline $\begin{array}{l}\text { Connecticut } \\
\text { New Jersey } \\
\text { Virginia }\end{array}$ & $\begin{array}{l}2584.1 \\
2841.6 \\
2067.4\end{array}$ & $\begin{array}{l}0.17 \\
0.17 \\
0.23\end{array}$ & $\begin{array}{l}2.04 \\
2.74 \\
3.10\end{array}$ & $\begin{array}{l}1.82 \\
1.74 \\
1.80\end{array}$ \\
\hline
\end{tabular}

Source: See Appendix. 
would be extremely wasteful of human resources and would drive pupils from strongly supportive home environments and with high endowments of learning abilities out of the public school system. At the same time the costs of raising the achievement levels of the less well endowed are likely to exceed any conceivable measure of benefits long before we should have realized equal educational achievement.

If all children possessed equal endowments and were subject to identical non-school environmental factors, equal school expenditures might bring equality in educational achievement. But even with equal expenditures among school districts equal achievement might not be attained. Equal numbers of dollars do not ensure equal quality or even quantity of resources; wages and salaries vary, as does the quality of teachers, principals, support staff, and other inputs, and so does the efficiency with which these resources are used to produce educational outcomes. Moreover, the distribution of funds among schools within districts, or within schools among classrooms, may not be equal. And once it is recognized that pupils possess a wide range of personal endowments and are exposed to vastly differing non-school environments, it becomes apparent that equal achievement is not even remotely related to equal expenditures.

Alternatively, equity in school finance may be defined as equal educational opportunity. This definition requires that a pupil's chances for success in acquiring cognitive and social skills be independent of the school he attends. It recognizes the limitations of the role of the schools in determining levels of educational achievement. It acknowledges implicitly the influence of differences in home and neighborhood environments, in private supplements to the public school experience, and in the personal endowments of the pupil that make for higher or lower levels of educational achievement.

Equality of educational opportunity defined in this way seeks the more attainable equality among schools rather than among pupils. Our educational system, then, would be equitable when the level of educational achievement attained by a child is independent of the school he attends.

Does this objective require equal per pupil expenditures? Perhaps the most that can be said for the part played by differences in dollar outlays for education is that more dollars afford more scope for pursuing ways and means of inducing pupils to learn more; they may facilitate the learning process. We expect that reducing variance in expenditures should bring us closer to equal educational opportunity; it is difficult to imagine that the direction of its influence can be otherwise. The available evidence suggests, however, that the magnitude of the change attainable with a more equal spread of dollars is rather narrowly limited. ${ }^{7}$

Thus reducing inequality in expenditures may be viewed as a desirable policy objective, but not one to be pursued without regard for other concerns. Its merit lies in its capacity to move the system some unknown distance toward the goal of equal educational opportunity. But there are costs associated with reducing inequality. Reduction in inequality may be attainable only at the expense of economic efficiency.

\section{Equity and Efficiency}

Advocates of equal expenditures have often envisioned a state centralized system of financing education, such as obtained in Hawaii and in most of the world outside of North America. But, as Table 1 indicates, the demand for education varies widely among school districts, and therefore any imposed uniform level of expenditures will involve substantial welfare losses. This follows because that level will be higher than some communities would demand and lower than would be preferred by others. Figure 1, in which it is assumed that there are two districts, one exhibiting a higher and the other a

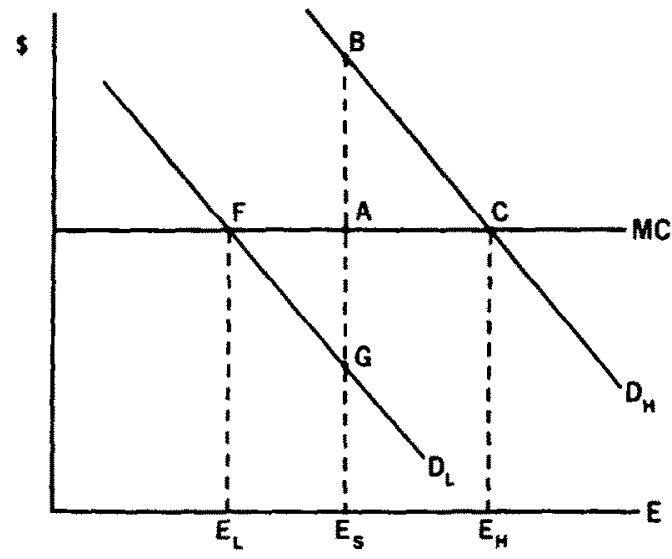

Figure 1. 
lower demand for education expenditures than a state-mandated level, illustrates the point. We assume that they both face the same constant cost of education expenditure.

The state mandated level of school expenditures is given by $E_{s}$, the high- and low-demand districts' compensated demand curves are $D_{H}$ and $D_{L}$, while the levels preferred by the high- and low-demand districts, respectively, given their incomes, prices, and preferences, are $E_{H}$ and $E_{L}$. For the highdemand district, the welfare loss associated with the state mandated level of expenditure is measured by the triangular area $A B C$, the excess of the value to it of $E_{S} E_{H}$ units of education over their cost, $A C E_{H} E_{S}$. For the low-demand district, the welfare loss is given by the area AFG, the excess of the cost of $E_{L} E_{S}$ dollars of expenditure over their value to the district, $F G E_{S} E_{L}$. The welfare loss to the state as a whole is the sum of the two triangles. From an economic efficiency standpoint welfare would be enhanced by allowing the high-demand district to spend more and the low-demand district less than the state determined $E_{S}{ }^{8}$

Thus if equity is sought through mandated equality of expenditures the outcome may reflect neither equity nor efficiency, given the inadequacy of equal expenditures as an equity criterion. Furthermore, if a state did choose to accept welfare losses to achieve equality of expenditure, much of what might appear to be gained in terms of equality of educational opportunity would be illusory. In fact people in the high-demand district are likely to spend more than the state allowance, either by supplementing the public school experience with lessons in the private sector or by moving into the private school system. In districts where state-mandated public school spending exceeds the demand for education, on the other hand, we should expect less than full use of the available resources.

Nevertheless, states may wish to move in the direction of reducing inequalities in per pupil expenditures among districts insofar as they reflect more than different preferences. These inequalities also reflect large differences among districts in income and property wealth, differences that may frustrate preferences and lead to educational deprivation. Even after recognizing the limited influence of differences in expenditures on educational outcomes, ratios of two to one and higher in per pupil expenditures are likely to represent far less than equality of educational opportunity.
The challenge is to find a means of reducing inequality in educational opportunity without imposing social costs as large as those involved in state mandated equality of expenditures. This requires leaving budgetary decision making in the hands of the local community while influencing that process through state policy. The goal in the design of appropriate policy instruments is to compensate for differences in resources and in income while leaving scope for the play of community preferences and priorities. Some sacrifice of efficiency seems inevitable and should be recognized as a cost of improving equity.

When we confront the question of the ways in which the state may exert its influence on local demand for education expenditure we find that its opportunities are limited. The only major determinant of demand that is readily amenable to effective state policy intervention is tax price.

Raising or lowering districts' tax prices enables a state to induce them to spend less or more than they otherwise would. Thus, as we illustrate in Fig. 2, the high-demand district facing an increase in tax price reduces its expenditures from $E_{H}$ to $E_{H}{ }^{\prime}$, while the low-demand district, experiencing a cut in tax price, moves up from $E_{L}$ to $E_{L}^{\prime}$. While less cquality is achieved than with a state mandated expenditure level, efficiency losses are considerably smaller triangles $B C D$ and $\mathrm{GHI}$ rather than $\mathrm{ACE}$ and $\mathrm{AFI}$. The more the state alters tax prices, the more equality it can achieve and the larger efficiency losses become. ${ }^{9}$

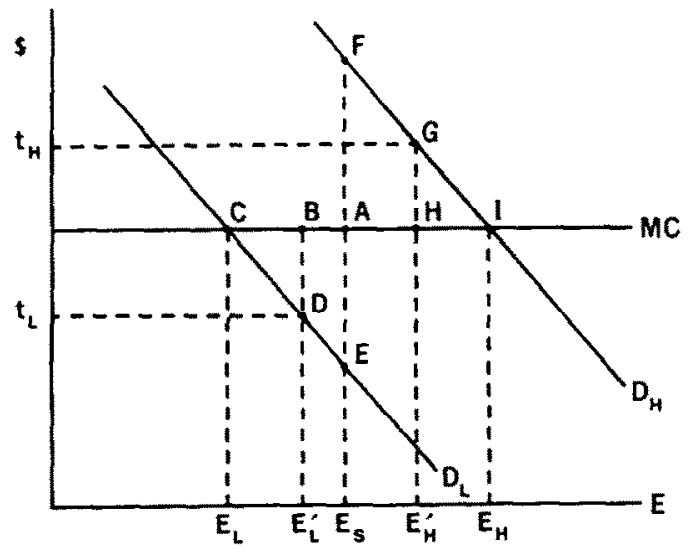

Figure 2. 


\section{STATE MATCHING-AID POLICY ALTERNATIVES}

Tax price, $P_{e}$, given by the expression ${ }^{10} P_{e}=$ $\left(H_{m} / V\right)(1-m)(1-m t r) n$, is readily subject to manipulation by the state. For purposes of our analysis we assume that $n$, the number of pupils, is given and is not subject to policy control, and that the same is true of $m t r$, the marginal income tax rate of the median taxpayer, $H_{m}$, the local tax base of that taxpayer, and $V$, the total local tax base. Thus the extent to which $P_{e}$ is subject to policy control will depend on how we define the matching rate, $m,{ }^{11}$ and the impact on expenditures of changes in $P_{e}$ will depend on the elasticity of demand for education.

\section{Equal Yield}

One possible definition of $m$ derives from a policy position that argues that the ability of each school district to raise funds should be independent of the size of its per pupil tax base, typically state equalized value of taxable property per pupil ( $S E V)$. Thus we define $m$ as $\left(1-S E V_{i} / S E V_{s}\right)$, where $S E V_{i}$ is the individual district's $S E V$ and $S E V_{s}$ is the state support level of $S E V$. This definition of $m$ yields what has been variously called "district power equalizing" (DPE) (Coons et al., 1971), percentage equalization, or equal yield. This type of state aid ensures that each district realizes the same amount of revenue per pupil per mill in its tax rate as every other district in the state.

Under equal yield, with $m$ defined as 1 $S E V_{i} / S E V_{s}$, irrespective of the district's tax base its revenues per pupil per mill in its levy is $\$ 0.001 S E V_{s}$. Thus, for example, if $S E V_{s}$ is set at $\$ 100,000$, a district levying 20 mills on $S E V_{i}$ of $\$ 50,000$ would realize $\$ 1000$ per pupil from its levy and would receive $\$ 1000$ from the state. A "rich" district, with $S E V_{i}$ of $\$ 200,000$, would realize $\$ 4000$ from the same tax rate and would remit $\$ 2000$ to the state. Each district would have revenues equal to $\$ 2000$ per pupil. Note that $m$ for the low $S E V$ district is 0.5 and for the high $S E V$ district it is -1 . Equal yield reduces $P_{e}$ by half in the one case and doubles it in the second.

Existing tax prices in Connecticut, New Jersey, and Virginia are functions of their current definitions of $m$. The aid formula for each of these states falls well short of full DPE or equal yield. ${ }^{12}$ These formulas produce tax prices that are higher than they would be under full-blown equal yield for most districts with tax bases per pupil $\left(S E V_{i}\right)$ lower than our assumed state support level. High $S E V$ districts, on the other hand, will experience increases in tax price under DPE.

\section{Equal Yield with Income Weighting}

Since our estimated tax price elasticities of demand range from -0.14 in New Jersey to -0.32 in Connecticut, ${ }^{13}$ we know that the expenditure equalizing effects of DPE will vary among the states. Given these elasticities we also know that it will take large changes in tax price to bring about appreciable expenditure equalization.

A frequently voiced criticism of DPE holds that it is not an effective equalizing mechanism because it does not take differences in income into account. And, as we have indicated, our demand equations suggest that expenditures for education are sensitive to differences among school districts in levels of median family income..$^{14}$ DPE is easily modified to take relative income into account. This is done by attaching an income weight to $m$. In this alternative formulation $m_{y}=\left[1-\left(S E V_{i} / S E V_{s}\right)\left(Y_{i} / Y_{s}\right)\right]$, where $S E V_{i}$ and $S E V_{s}$ are as previously defined and $Y_{s}$ and $Y_{i}$ are median family income for the state and for the school district. This alternative yields a definition of tax price as $P_{e y}=\left(H_{m} / V\right)\left(1-m_{y}\right)(1-m t r) n$.

The virtue of this approach is that it recognizes that the same tax price will not give rise to the same expenditure per pupil where one of two districts is a low income industrial enclave or rural resort community, while the other is a high income suburb. Estimates of income and price elasticities lend credence to the expectation that the lower income districts will often spend less, even where tax price is lower, other things equal. This follows from the fact that the elasticities estimated for income are substantially greater in absolute terms than the price elasticities. ${ }^{15}$

In Table 2 we present descriptive statistics for tax price under three alternatives, each of which carries the same budgetary cost to the state. They are the aid system in effect in 1981-1982, full DPE, and income-weighted DPE. In general moving to DPE reduces the mean tax price, but it increases it for property rich districts, where $S E V_{i}$ exceeds $S E V_{s}$, and reduces it for property poor districts. ${ }^{16}$ But going from DPE to DPE-Income tends to increase average tax price while reducing it for relatively low 
income districts and raising it for those with high median family incomes.

The estimated price elasticities of demand of $-0.32,-0.14$, and -0.28 for Connecticut, New Jersey, and Virginia ${ }^{17}$ tell us that a $1 \%$ change in tax price will bring a state-average change in per pupil expenditure ranging from about $1 / 7$ to $1 / 3$ of $1 \%$. We have estimated the expected effects of changing tax prices by introducing DPE and DPE-Income. The results of our simulation experiment follow.

\section{SIMULATION RESULTS}

Using equations that relate education expenditure per pupil to its determinants, we can simulate the effects of implementing full DPE or DPE-Income. We use our estimated regression coefficients for Connecticut, New Jersey, and Virginia (which are reprinted in Appendix A) to predict districts' 19811982 expenditure per pupil under these matching aid plans. ${ }^{18}$

We present in Table 3 results for the three policy options for which descriptive statistics on tax prices are found in Table 2. Our benchmark levels of expenditure are given by the values that obtained under the aid programs actually in effect in 19811982. However, the values to be seen in the rows labeled "Actual aid" are predicted values from the regression equations rather than the observed values. We opted for this approach in order to

Table 2. Tax prices under various matching aid plans

\begin{tabular}{|c|c|c|c|c|c|}
\hline & Minimum & Maximum & Mean & SD & Coefficient of variation \\
\hline & \multicolumn{5}{|c|}{ Connecticut } \\
\hline Actual aid & 0.09 & 0.42 & 0.28 & 0.05 & 0.18 \\
\hline DPE & 0.19 & 0.56 & 0.26 & 0.07 & 0.27 \\
\hline \multirow[t]{2}{*}{ DPE-Income } & 0.12 & 1.07 & 0.28 & 0.17 & 0.61 \\
\hline & \multicolumn{5}{|c|}{ New Jersey } \\
\hline Actual aid & 0.07 & 2.34 & 0.40 & 0.21 & 0.52 \\
\hline DPE & 0.10 & 0.70 & 0.32 & 0.09 & 0.28 \\
\hline \multirow[t]{2}{*}{ DPE-Income } & 0.04 & 1.19 & 0.35 & 0.20 & 0.57 \\
\hline & \multicolumn{5}{|c|}{ Virginia } \\
\hline Actual aid & 0.03 & 0.61 & 0.28 & 0.10 & 0.36 \\
\hline DPE & 0.10 & 0.27 & 0.15 & 0.03 & 0.20 \\
\hline DPE-Income & 0.05 & 0.36 & 0.12 & 0.05 & 0.42 \\
\hline
\end{tabular}

Table 3. Predicted education expenditure per pupil under various matching aid plans

\begin{tabular}{|c|c|c|c|c|c|}
\hline & Minimum & Maximum & Mean & SD & Coefficient of variation \\
\hline & \multicolumn{5}{|c|}{ Connecticut } \\
\hline Actual aid & 1839.6 & 3734.7 & 2584.1 & 395.43 & 0.15 \\
\hline DPE & 1892.2 & 3390.4 & 2628.9 & 265.63 & 0.10 \\
\hline \multirow[t]{2}{*}{ DPE-Income } & 1874.6 & 3842.1 & 2643.7 & 286.14 & 0.11 \\
\hline & \multicolumn{5}{|c|}{ New Jersey } \\
\hline Actual aid & 1756.2 & 4230.3 & 2841.6 & 359.23 & 0.13 \\
\hline DPE & 1502.9 & 3328.1 & 2470.4 & 281.19 & 0.11 \\
\hline \multirow[t]{2}{*}{ DPE-Income } & 1467.0 & 3304.1 & 2474.1 & 272.28 & 0.11 \\
\hline & \multicolumn{5}{|c|}{ Virginia } \\
\hline Actual aid & 1612.9 & 4258.7 & 2067.4 & 425.24 & 0.21 \\
\hline DPE & 1707.5 & 4071.7 & 2149.5 & 387.06 & 0.18 \\
\hline DPE-Income & 1720.7 & 4010.0 & 2188.4 & 376.13 & 0.17 \\
\hline
\end{tabular}


isolate the effects of changes in the aid formula from differences between observed and predicted values attributable to errors of estimation.

\section{Overall Results}

Our measure of variance among districts in educational expenditures per pupil is the coefficient of variation. ${ }^{19}$ Under the existing system of aid this coefficient ranges from 0.13 in New Jersey to 0.21 in Virginia. In each of the states our simulations predict that DPE would reduce variance in levels of expenditure. The most dramatic change is seen in Connecticut, where the coefficient of variation is 0.10 under DPE and 0.15 under the actual aid formula. Inevitably the effects are smaller in New Jersey and Virginia because the estimated price elasticities are substantially smaller in those states than in Connecticut.

Shifting from the existing state aid system to DPE appears to affect the average level of school expenditures to varying degrees across states. In Connecticut and Virginia it brings a modest increase in expenditures, whereas in New Jersey mean outlays fall sharply, from $\$ 2842$ to $\$ 2470$. In Connecticut and Virginia, property poor districts increase their expenditures by more than the rich districts reduce their's, whereas in New Jersey quite the opposite occurs. ${ }^{20}$ It is also interesting to observe that, in each of the states, moving from DPE to DPE-Income has no appreciable effect on levels of expenditure; the higher outlays of low income districts are offset almost exactly by reductions in high income districts.

The DPE-Income aid plan appears to have relatively little effect on the degree of equality compared with DPE. But the statistics presented in Table 4 suggest that this plan may be preferred because of its impact on the size and direction of the influence on predicted expenditures of property wealth $(S E V)$ and median family income $(Y)$. For all three states we find that these two variables are highly and positively correlated with expenditure levels under the existing aid system. The shift to DPE reduces the correlation coefficients appreciably in Connecticut and New Jersey but not in Virginia, and moving to DPE-Income yields small but consistently negative coefficients for the first two states. Neither of the alternative aid policies produces changes in any relevant dimensions for Virginia, essentially because our estimating
Table 4. Correlation between predicted expenditure, SEV per pupil, and median family income under various matching aid plans

\begin{tabular}{|c|c|c|}
\hline Predicted expenditure with & $S E V$ & $Y$ \\
\hline & \multicolumn{2}{|c|}{ Connecticut } \\
\hline Actual aid & 0.75 & 0.54 \\
\hline DPE & 0.28 & 0.37 \\
\hline \multirow[t]{2}{*}{ DPE-income } & -0.13 & -0.35 \\
\hline & \multicolumn{2}{|c|}{ New Jersey } \\
\hline Actual aid & 0.40 & 0.55 \\
\hline DPE & -0.11 & 0.28 \\
\hline \multirow[t]{2}{*}{ DPE-Income } & -0.25 & -0.04 \\
\hline & \multicolumn{2}{|c|}{ Virginia } \\
\hline Actual aid & 0.61 & 0.47 \\
\hline DPE & 0.50 & 0.46 \\
\hline DPE-Income & 0.50 & 0.40 \\
\hline
\end{tabular}

equation for that state contains a price elasticity coefficient that approaches zero.

\section{Individual Districts}

While it is instructive to examine the impact of alternative aid systems on the overall picture for the distribution within states of per pupil expenditures, it may be even more revealing to look at the changes brought about among individual districts. Table 5 is designed to provide some important insights with respect to the effects of alternative aid plans on the expenditure ranking of selected districts within each state, the five wealthiest and the five poorest in terms of $S E V$, and the five largest. Rankings of predicted expenditure are presented for each of three aid options.

In Connecticut, the expenditure rankings of many districts change dramatically as we substitute one aid plan for another. Hartford, for example, which ranks lowest among Connecticut districts with respect to both income and property wealth, still managed to rank $21 \mathrm{st}$ out of 99 districts in our sample in 1981-1982 in terms of per pupil education expenditures. Under DPE we estimate it would move up to rank 4, while under DPE-Income it would rank 1. Each of the others among the state's lowest ranking districts in terms of $S E V$ would improve its ranking substantially, but only Wolcott would rise above the median.

Among Connecticut's richest districts, measured by $S E V$, all five were among the top ten highest spending districts under the prevailing aid system. 
Table 5. Predicted rankings of selected districts by expenditure per pupil under alternative aid plans

\begin{tabular}{|c|c|c|c|c|c|}
\hline \multicolumn{6}{|c|}{ Connecticut } \\
\hline District & $S E V$ rank & $Y_{\text {rank }}$ & Actual rank & DPE rank & DPE-Income rank \\
\hline \multicolumn{6}{|c|}{ Lowest-SEV districts } \\
\hline Hartford & 99 & 99 & 21 & 4 & 1 \\
\hline Plainfield & 98 & 94 & 96 & 96 & 78 \\
\hline Naugatuck & 97 & 85 & 90 & 81 & 56 \\
\hline Thompson & 96 & 91 & 99 & 98 & 91 \\
\hline Wolcott & 95 & 63 & 78 & 58 & 50 \\
\hline \multicolumn{6}{|c|}{ Highest-SEV districts } \\
\hline Greenwich & 1 & 7 & 2 & 37 & 81 \\
\hline Waterford & 2 & 65 & 9 & 76 & 67 \\
\hline New Canaan & 3 & 1 & 5 & 14 & 90 \\
\hline Darien & 4 & 5 & 8 & 15 & 76 \\
\hline Stamford & 5 & 26 & 6 & 12 & 19 \\
\hline Largest districts & \multicolumn{2}{|c|}{ Number of pupils } & & & \\
\hline Waterbury & \multicolumn{2}{|c|}{14,074} & 43 & 16 & 4 \\
\hline Stamford & \multicolumn{2}{|c|}{14,183} & 6 & 12 & 19 \\
\hline New Haven & \multicolumn{2}{|c|}{18,131} & 31 & 18 & 2 \\
\hline Bridgeport & \multicolumn{2}{|c|}{20,063} & 50 & 45 & 8 \\
\hline Hartford & \multicolumn{2}{|c|}{25,003} & 21 & 4 & 1 \\
\hline \multicolumn{6}{|c|}{ Number of districts $=99$} \\
\hline \multicolumn{6}{|c|}{ New Jersey } \\
\hline District & $S E V$ rank & $Y$ rank & Actual rank & DPE rank & DPE-Income rank \\
\hline \multicolumn{6}{|c|}{ Lowest-SEV districts } \\
\hline Camden & 380 & 380 & 347 & 150 & 15 \\
\hline North Hanover & 379 & 360 & 379 & 367 & 356 \\
\hline Newark & 378 & 378 & 257 & 33 & 2 \\
\hline Pemberton & 377 & 338 & 356 & 251 & 205 \\
\hline East Orange & 376 & 359 & 219 & 34 & 5 \\
\hline \multicolumn{6}{|c|}{ Highest-SEV districts } \\
\hline Carlstadt & 1 & 232 & 75 & 292 & 272 \\
\hline Englewood Cliffs & 2 & 11 & 2 & 103 & 203 \\
\hline North Wildwood & 3 & 355 & 184 & 334 & 292 \\
\hline Ocean City & 4 & 321 & 65 & 257 & 218 \\
\hline Cape May & 5 & 364 & 175 & 326 & 267 \\
\hline Largest districts & \multicolumn{2}{|c|}{ Number of pupils } & & & \\
\hline Elizabeth & & & 211 & 116 & 68 \\
\hline Camden & & & 347 & 150 & 15 \\
\hline Paterson & & & 349 & 243 & 163 \\
\hline Jersey City & & & 204 & 30 & 3 \\
\hline Newark & & & 257 & 33 & 2 \\
\hline
\end{tabular}

Number of districts $=380$ 
Table 5. Continued.

\begin{tabular}{|c|c|c|c|c|c|}
\hline District & $S E V$ rank & $Y$ rank & $\begin{array}{l}\text { Virginia } \\
\text { Actual rank }\end{array}$ & DPE rank & DPE-Income rank \\
\hline \multicolumn{6}{|l|}{ Lowest-SEV districts } \\
\hline Russell County & 121 & 89 & 118 & 112 & 110 \\
\hline Scott County & 120 & 119 & 121 & 118 & 114 \\
\hline Buena Vista & 119 & 80 & 96 & 81 & 81 \\
\hline Manassas Park & 118 & 17 & 38 & 19 & 21 \\
\hline Buchanan County & 117 & 66 & 114 & 104 & 107 \\
\hline \multicolumn{6}{|l|}{ Highest-SEV districts } \\
\hline Surry County & 1 & 97 & 11 & 25 & 22 \\
\hline Louisa County & 2 & 83 & 51 & 82 & 82 \\
\hline Arlington County & 3 & 3 & 1 & 1 & 1 \\
\hline Bath County & 4 & 101 & 8 & 10 & 10 \\
\hline Falls Church & 5 & 2 & 3 & 3 & 3 \\
\hline Largest districts & \multicolumn{2}{|c|}{ Number of pupils } & & & \\
\hline Chesterfield County & \multicolumn{2}{|c|}{33,741} & 87 & 86 & 93 \\
\hline Norfolk & \multicolumn{2}{|c|}{34,789} & 10 & 9 & 8 \\
\hline Prince William County & \multicolumn{2}{|c|}{35,263} & 67 & 69 & 75 \\
\hline Virginia Beach & \multicolumn{2}{|c|}{54,482} & 44 & 46 & 53 \\
\hline Fairfax County & \multicolumn{2}{|c|}{121,470} & 6 & 8 & 9 \\
\hline Number of districts $=1$ & & & & & \\
\hline
\end{tabular}

Moving to DPE pushes all of them out of the top ten, with Waterford and Greenwich being affected most drastically as they drop to ranks 76 and 37 , respectively. All but Waterford among the richest districts fall further with the substitution of DPEIncome, under which New Canaan would rank 90th. Waterford's position is actually slightly improved under this switch because, while it enjoys a very high $S E V$, its $Y$ is well below the state average.

Among the state's largest central city school districts Hartford, as we have seen, moves up sharply as we shift toward DPE-Income, and Waterbury, New Haven, and Bridgeport all make it to the top ten under this approach. The relatively rich Stamford district, as expected, moves down.

Changes in districts' rankings are determined by our estimated tax price and basic aid coefficients (under both DPE plans, tax price values change and non-matching basic aid falls to zero), as well as by the particular values of those variables in each district. For example, Hartford's actual tax price is ranked 19th out of the 99 districts in our Connecticut sample, but its tax price would be ranked 67 th under DPE and 99th under DPE-Income. This change in tax price ranking results in Hartford's dramatic increase in predicted expenditure ranking under DPE-Income.

Similar patterns appear in New Jersey. Camden and Newark, among the state's poorest and largest districts, change their rankings from 347 and 257 out of 380 under the aid system of 1981-1982 to 150 and 33 under DPE and 15 and 2 under DPE-Income. East Orange also experiences a large upward movement as it goes from ranking 219 to 5. Jersey City too would benefit enormously from a shift in aid plan to DPE-Income.

Among New Jersey's highest $S E V$ districts Cape May, a resort community with low $Y$, would fare poorly under DPE, somewhat better under DPEIncome, while Englewood Cliffs, rich under both criteria, would drop sharply from a ranking of 2 to 203 in school expenditures.

Not much can be made of our simulations for Virginia. The low estimated price elasticity simply precludes there being any appreciable impact from changes in the aid formula that work through their influence on tax price. ${ }^{21}$

Further insights into the impact on district expenditures of the introduction of a DPE-Income aid plan may be gained by computing the difference 
between predicted expenditure with DPE-Income and with actual aid, and regressing this variable on $S E V$ and $Y{ }^{22}$ The coefficients of both variables should be negative - higher property wealth and income will lead to higher tax prices under DPEIncome and, consequently, to smaller increases or to decreases in expenditures.

The results of this regression are presented in Table 6. For Connecticut, they indicate that, on average, $\$ 10,000$ more in $S E V$ or $\$ 1000$ more in $Y$ would be associated with a $\$ 28$ drop in district expenditures per pupil if the State were to adopt DPE-Income aid. For New Jersey the same increase in $S E V$ would bring a drop of $\$ 15$ in expenditures and a $\$ 1000$ increment in income a reduction of $\$ 22$. Predicted effects are far smaller for Virginia, again because of its low tax price elasticity. ${ }^{23}$

\section{SUMMARY AND CONCLUSIONS}

Equity, in education finance as elsewhere, is an elusive concept. We reject the notion that its achievement requires equal per pupil expenditure among school districts. We come, rather, to the conclusion that it may best be defined in terms of equality of educational opportunity, defined to mean that a pupil's success or failure in acquiring cognitive and social skills is independent of the school he or she attends. Our observation of the distribution of expenditures among school districts in Connecticut, New Jersey, and Virginia strongly suggests that equity as so defined is not being realized. And it seems to us a fair presumption that more equal expenditures would bring equal edu-

Table 6. Determinants of differences in predicted expenditure per pupil generated by introduction of a DPEIncome aid plan*

\begin{tabular}{lccc}
\hline & Connecticut & New Jersey & Virginia \\
\hline Constant & 1234.8 & 436.0 & 386.3 \\
& $(38.32)$ & $(27.25)$ & $(32.25)$ \\
SEV & -0.0028 & -0.0015 & -0.0006 \\
& $(-24.36)$ & $(-33.05)$ & $(-25.63)$ \\
$Y$ & -0.028 & -0.022 & -0.009 \\
$n$ & $(-19.17)$ & $(-32.13)$ & $(-13.39)$ \\
$R^{2}$ & 99 & 380 & 121 \\
& 0.96 & 0.90 & 0.90 \\
\hline
\end{tabular}

t-ratios are in parentheses.

* Dependent variable $=$ Predicted expenditure under a DPE-Income aid plan minus predicted expenditure under the State's actual aid plan. cational opportunity closer to realization than it is now.

We recognize, however, that inducing some districts to spend more and some less necessarily entails social costs that rise with the dimensions of the inducements, the extreme case being state mandated equality of expenditures among districts. We are, therefore, involved in the trade-off between equity and efficiency. Our suggested compromise is a distinct power equalizing (DPE) aid plan or a DPE plan modified to account for income (DPE-Income), either of which would achieve substantial equalization in New Jersey and Connecticut.

Perhaps the most objectionable feature of these plans and the simulated results that follow from their adoption is that they would induce the richer districts in these states to cut educational expenditures sharply. It is not apparent to us that this would be of benefit to anyone or that it represents the most desirable way of partially funding higher outlays by the poorer districts. Throughout our simulations we have assumed that the states' contributions to local school funding through non-categorical aid would remain at their actual 1981-1982 levels. But this assumption may render the DPE plans both politically and philosophically unacceptable. This is true particularly in New Jersey, where introduction of DPE in either form would bring so large a reduction in the expenditures of the richer districts that total school expenditures would fall sharply.

Full DPE requires the richer districts to contribute portions of their tax levies to the state for redistribution to poorer districts. It is difficult to imagine that many of the richer districts would find this tolerable. Moreover, it is this contribution to the state pool of funds that raises the tax price of education for rich districts and leads to curtailment of their expenditures and, very likely, to a loss of public support for education. On balance there may be gains in equity, but it is not clear that the costs of their attainment do not exceed the value of those gains.

The judgement at which we arrive is that it is possible to realize major gains in equity, albeit while incurring substantial efficiency losses, but the outlook for so doing is not bright unless the states are willing and able to increase their participation in funding education. It is unlikely to be possible or even desirable to increase adequately funding for poorer districts exclusively at the expense of richer 
districts. Rather, it is the state's revenue system as a whole that must assist poorer districts if equal educational opportunity is to be a politically attainable goal at a cost that is reasonably sustainable.

\section{NOTES}

1. See, for example, the position of plaintiffs in Serrano v. Priest, 5 Cal.3d 584, 487 P.2d 1211, 96 Cal.Rptr. 601 (1971) and San Antonio Independent School District v. Rodriguez, 411 U.S. 1 (1973).

2. For a review of school finance litigation and court decisions, see Lindquist and Wise (1976).

3. Public Economics offers virtually no support for equality of expenditures for education. The fact that most identifiable benefits deriving from elementary and secondary education are appropriable by the consumer-pupil renders education a "private good", one that is both publicly and privately supplied in this country. It may be said to differ from other private goods to the extent that its consumption gives rise to externalities or benefits enjoyed by the population at large, directly or indirectly. That is, in Professor Musgrave's terms it is a good satisfying a "merit want" (Musgrave, 1958). This characteristic argues for subsidizing its consumption, so that expenditure on it may exceed the level that would obtain if external benefits were ignored. But it says nothing in support of equalizing expenditures - everyone's consumption of education should be subsidized. Equalization must, therefore, rest on other grounds, grounds having more to do with philosophical notions of justice and with one's faith in education as the means of achieving social mobility than with economics. At the same time efforts to find mandates for equality of expenditures in constitutional language are quite beside the point in a normative discussion of the issue, and presumably only lawyers are qualified to seek positive meanings in that language.

4. Tax price is defined as the cost to the median taxpayer of an additional dollar of expenditure per pupil for elementary and secondary education. It may be expressed as $P_{e}=\left(H_{m} / V\right)(1-m)(1-$ $m t r) n$, where $H_{m}$ is the median taxpayer's local tax base (typically his home), $V$ is the total local tax base, $m$ is the rate at which the state matches local school expenditures, mtr is the marginal income tax rate of the median taxpayer in the community, and $n$ is the number of pupils.

5. Among suits brought in behalf of such children are Robinson v. Cahill, 70 N.J. 464, 360 A.2d 400 (1976) in New Jersey and Bd. of Educ., Levittown Union Free School District v. Nyquist, 453 N.Y.S. 643 (1982) in New York.

6. For a detailed discussion of measures of equity in school finance, see Berne and Stiefel (1984).

7. Extensive studies of the educational production function have shown consistently that those things that money can buy for schools play only a minor role in determining children's educational attainments. See, for example, Bowles (1970) and Summers and Wolfe (1977).

8. This analysis treats education as though it were a purely private good. To the extent that it generates positive externalities, the welfare loss triangles in Figs 1 and 2 may be overstated.

9. All of this reasoning rests, of course, on the assumption, generally supported by the findings of empirical studies of demand for education, that tax price and education expenditure are negatively correlated, and that state policy will yield changes in tax prices that are positive for high spending and negative for low spending districts.

10. See note 4 supra.

11. $m$ may apply either to total expenditures in the school district for education or to the local share of that expenditure. If it applies to the total it appears in the expression defining tax price as indicated in the text; if it applies to the local share it enters the definition of tax price in the term $(1 / 1+m)$. When $m=1$ in the latter case it is 0.5 in the former.

12. A good source of information on state aid formulas is Tron (1980). Also see State of Connecticut Board of Education, Guaranteed Tax Base: Grant Calculation Workbook, Hartford, CT, Virginia Education Association, $A B C s$ of School Finance, Richmond, VA, and Salmon et al. (1988).

13. The estimated coefficients for our education expenditure equations are presented in Appendix $A$.

14. The income elasticities are $0.62,0.32$, and 0.48 , for Connecticut, New Jersey, and Virginia, respectively. Brazer and McCarty (1987), p. 559.

15. In line with the notion of the "flypaper effect", as expounded by Courant et al. (1979), among others, it might be thought that the appropriate way to respond to the demonstrated sensitivity to income would be through increasing lump sum grants, equivalent, theoretically, to increases in income when multiplied by tax share $\left(H_{m} / V\right)$. But this view is not supported by our earlier estimates, where the elasticities of expenditures with respect to lump sum grants (BASICAID) were consistently not significantly different from zero. Lump sum grants in these instances seem not only not to "stick where they hit", they appear, rather, to substitute for local taxes.

16. $S E V$, is determined in each state at the level which yields a total for basic or non-categorical state aid per pupil equal to the actual amount received in $1981-1982, \$ 567, \$ 790$, and $\$ 700$, respectively, in 
Connecticut, New Jersey, and Virginia. Thus it differs between the alternative forms of DPE while, as noted in the text, the states' budgetary costs remain constant.

17. We have had to perform the Virginia simulations using a revised version of the regression presented in Brazer and McCarty (1987). The coefficient for BASICAID in that regression is negative and relatively large $(-0.14)$. As a result, the simulations performed with that regression yield results that are improbable in the extreme. We have re-estimated the equation with aid in per pupil form instead of being multiplied by tax share. The resulting aid coefficient estimates are more in line with our expectations, permitting us to proceed with the simulation exercise. It should be noted, however, that the estimated tax price coefficient falls from -0.28 to -0.07 when we make this change in BASICAID.

18. In New Jersey, the aid formula in effect in 1981-1982 reimburses districts for a fraction of their expenditure in the year after the expenditure is made. There is some disagreement as to whether or not this constitutes matching aid. We have chosen not to treat it as such; however, we have run our New Jersey regression with the alternative assumption, that New Jersey's equalization aid is matching aid. When we do this, the estimated tax price coefficient falls from -0.14 to -0.07 . If the matchingaid specification is the correct one, then changing tax prices by implementing DPE or DPE-Income aid would have smaller effects on expenditure than our simulation results predict.

19. The coefficient of variation is the S.D. divided by the mean.

20. The change in a district's expenditure when DPE aid is implemented is a function of both the tax price and the lump-sum basic aid coefficients in the regressions that are the basis of these simulation results. Under DPE aid, all aid is matching; existing lump-sum aid is eliminated. New Jersey's lumpsum basic aid coefficient is of the opposite sign and is considerably larger in magnitude than those of the other states (NJ: 0.0127; CT: -0.0016 ; VA: -0.0005 ). Therefore, when lump-sum aid falls from a fairly large positive number to zero, the New Jersey simulations show a fairly large decrease in expenditure per pupil. Furthermore, given that the tax price coefficient in New Jersey is quite small, there is relatively little increase in expenditure from matching aid to offset this decrease. Hence, we see an overall fall in average expenditure per pupil in New Jersey under DPE.

21. See note 17, supra. As observed there, the elasticity coefficient estimated for basic aid was negative, suggesting that lump sum aid would be even more futile. Altogether these results make it clear that our estimating equation for Virginia is wholly inadequate.

22. We compare predicted expenditures under DPE-Income with predicted, rather than observed, expenditures under the actual system in order to isolate the influence of the change in aid plan from differences attributable to errors of estimation arising from the fact that our equations contain error terms that are greater than zero. The differences in predicted expenditures that constitute our sets of dependent variables reflect only the change in tax price.

23. The simulations all assume that each of the districts in a state has a price elasticity of demand for education equal to the estimated state average elasticity. Estimates for individual districts based on longitudinal data might, of course, vary widely. Hence our results should be regarded as suggestive rather than definitive. We are indebted to the editor of this journal for urging that this point be recognized explicitly.

\section{REFERENCES}

Bd. of Educ. (1982) Leviltown Union Free School District v. Nyquist, 453 N.Y.S. 643.

Berne, R. and StIEFEt, L. (1984) The Measurement of Equity in School Finance. Baltimore: The Johns Hopkins University Press.

Bowles, S. (1970) Toward an educational production function. In Education, Income, and Human Capital (Edited by LEE, H.W.) New York: National Bureau of Economic Research.

Brazer, H.E. and McCarty, T.A. (1986) Municipal overburden: an empirical analysis. Econ. Educ. Rev. 6(4).

Brazer; H.E. and McCARTY, T.A. (1987) Interaction between demand for education and for municipal services. National Tax Journal 60(4).

Coons, J.E., Clune, W.H. and Sugarman, S.D. (1970) Private Wealth and Public Education. Cambridge, MA: Belknap Press.

Courant, P.N., Gramlich, E.M. and Rubinfeld, D. (1979) Public employee market power and the level of government spending. Am. Econ. Rev. 69(5).

LINDQuist, R. and WISE, A. (1976) Developments in education litigation: equal protection. J. Law Educ. 5(1).

Musgrave, R.A. (1958) The Theory of Public Finance. New York: McGraw-Hill.

Robinson v. Cahill, 70 N.J. 464, 360 A.2d 400 (1976).

SAlmon, R. et al. (1988) Public School Finance Programs of the United States and Canada, 1986-1987 
Blacksburg, Va.: American Educational Finance Association and Virginia Polytechnic Institute and State University, 1988.

San Antonio Independent School District v. Rodriguez, 411 U.S. 1 (1973).

Serrano v. Priest, 5 Cal.3d 584, 487 P.2d 1211, 96 Cal.Rptr. 601 (1971).

Summers, A.A. and Wolfe, A.B. (1977) Do schools make a difference? Am. Econ. Rev. 67(4).

Tron, E.O. (1980) Public School Finance Systems 1978-1979. Washington, DC: U.S. Government Printing Office.

\section{APPENDIX A}

DEMAND FOR EDUCATION EXPENDITURES PARAMETER ESTIMATES, 1981-1982

\begin{tabular}{|c|c|c|c|}
\hline Predictor variables & Connecticut & New Jersey & Virginia \\
\hline CONSTANT & $\begin{array}{r}4.4 \dagger \\
(1.7)\end{array}$ & $\begin{array}{c}5.4^{*} \\
(0.65)\end{array}$ & $\begin{array}{c}2.4 \\
(1.6)\end{array}$ \\
\hline TAXPRICE & $-0.32^{*}$ & $-0.14^{*}$ & $-0.28^{*}$ \\
\hline MEDFMY & $\begin{array}{c}0.62^{*} \\
(0.13)\end{array}$ & $\begin{array}{c}0.32^{*} \\
(0.060)\end{array}$ & $\begin{array}{c}0.48^{*} \\
(0.16)\end{array}$ \\
\hline BASICAID & $\begin{array}{c}-0.0016 \\
(0.0037)\end{array}$ & $\begin{array}{c}0.013 \\
(0.015)\end{array}$ & $\begin{array}{l}-0.14 \\
(0.076)\end{array}$ \\
\hline STCATAID & $\begin{array}{c}0.064 \\
(0.034)\end{array}$ & $\begin{array}{c}0.0025 \\
(0.0097)\end{array}$ & $\begin{array}{c}0.26^{*} \\
(0.085)\end{array}$ \\
\hline FEDAID & $\begin{array}{r}-0.0089 \\
(0.034)\end{array}$ & $\begin{array}{c}0.032^{*} \\
(0.0076)\end{array}$ & $\begin{array}{c}0.14^{*} \\
(0.036)\end{array}$ \\
\hline AGED & $\begin{array}{c}0.16^{*} \\
(0.059)\end{array}$ & $\begin{array}{c}0.090^{*} \\
(0.025)\end{array}$ & $\begin{array}{r}-0.0065 \\
(0.060)\end{array}$ \\
\hline SECPUP & $\begin{array}{r}-0.092 \\
(0.13)\end{array}$ & $\begin{array}{c}0.18^{*} \\
(0.050)\end{array}$ & $\begin{array}{c}0.049 \\
(0.15)\end{array}$ \\
\hline NOHS & $\begin{array}{r}-0.097 \dagger \\
(0.040)\end{array}$ & $\begin{array}{r}-0.047 \dagger \\
(0.021)\end{array}$ & $\begin{array}{c}0.046 \\
(0.066)\end{array}$ \\
\hline VOTE & $\begin{array}{c}0.18^{*} \\
(0.064)\end{array}$ & $\begin{array}{c}0.068 \dagger \\
(0.032)\end{array}$ & $\begin{array}{c}0.068 \\
(0.063)\end{array}$ \\
\hline PUPFM & $\begin{array}{c}0.12 \\
(0.12)\end{array}$ & $\begin{array}{c}0.076 \\
(0.050)\end{array}$ & $\begin{array}{c}-0.27 \dagger \\
(0.12)\end{array}$ \\
\hline ENRGR & $\begin{array}{r}-0.57^{*} \\
(0.19)\end{array}$ & $\begin{array}{c}-0.28^{*} \\
(0.10)\end{array}$ & $\begin{array}{c}-0.26 \\
(0.17)\end{array}$ \\
\hline OOC & $\begin{array}{c}-0.26^{*} \\
(0.080)\end{array}$ & $\begin{array}{c}-0.12^{*} \\
(0.028)\end{array}$ & $\begin{array}{r}-0.35^{*} \\
(0.11)\end{array}$ \\
\hline PRIV & $\begin{array}{c}0.015 \\
(0.023)\end{array}$ & $\begin{array}{c}0.029 \dagger \\
(0.013)\end{array}$ & $\begin{array}{c}-0.014 \\
(0.013)\end{array}$ \\
\hline POVT & $\begin{array}{l}0.00013 \\
(0.028)\end{array}$ & $\begin{array}{c}-0.013 \\
(0.015)\end{array}$ & $\begin{array}{c}-0.010 \\
(0.064)\end{array}$ \\
\hline PUP & $\begin{array}{c}-0.91^{*} \\
(0.24)\end{array}$ & $\begin{array}{c}-0.18 \dagger \\
(0.085)\end{array}$ & $\begin{array}{c}-0.21 \\
(0.15)\end{array}$ \\
\hline PUPSQ & $\begin{array}{c}0.057^{*} \\
(0.015)\end{array}$ & $\begin{array}{c}0.011 \dagger \\
(0.0055)\end{array}$ & $\begin{array}{c}0.012 \\
(0.0088)\end{array}$ \\
\hline DEPDIST & & $\begin{array}{c}-0.036 \\
(0.028)\end{array}$ & \\
\hline MEMB & & $\begin{array}{c}-0.13^{*} \\
(0.023)\end{array}$ & \\
\hline NONRS & $\begin{array}{c}-0.0077 \\
(0.0060)\end{array}$ & $\begin{array}{c}-0.0017 \\
(0.0041)\end{array}$ & \\
\hline SENT & $\begin{array}{c}-0.033^{*} \\
(0.011)\end{array}$ & $\begin{array}{c}-0.0080 \\
(0.0042)\end{array}$ & \\
\hline $\bar{R}^{2}$ & 0.77 & 0.55 & 0.73 \\
\hline$n$ & 99 & 380 & 121 \\
\hline SEE & 0.080 & 0.12 & 0.10 \\
\hline
\end{tabular}

Notes: Standard errors appear in parentheses. All regression equations are in log-linear form. Coefficients marked with a dagger $(\dagger)$ are significant at the $5 \%$ level, and those marked with an asterisk (*) are significant at the $1 \%$ level.

Source: Brazer and McCarty, 1986 and 1987. 
Variable definitions to accompany Appendix Table A:

TAXPRICE = The cost to the median voter in additional tax paid of an increase of one dollar in the level of expenditure per pupil.

MEDFMY $=$ Median family income

BASICAID = Lump-sum state aid (multiplied by the median voter's tax share)

STCATAID = Categorical state aid (multiplied by the median voter's tax share)

FEDAID = Federal aid (multiplied by the median voter's tax share)

AGED $=$ The proportion of the population over age 64

SECPUP $=$ The proportion of pupils in high school

NOHS $=$ The proportion of the adult population that has never finished high school

VOTE $=$ The proportion of Democratic voters

PUPFM = The number of pupils per family

ENRGR = The rate of enrollment growth

$\mathrm{OOC}=$ The proportion of residences that are owner occupied

PRIV $=$ The fraction of pupils who are enrolled in non-public schools

POVT $=$ The proportion of the population in poverty

PUP AND PUPSQ $=$ The number of pupils and the number of pupils squared

DEPDIST = A dummy variable identifying dependent as opposed to independent school districts

MEMB = A dummy variable identifying districts that are members of regional high school districts

NONRS = The proportion of non-resident pupils

SENT $=$ The proportion of pupils sent to school in other districts

For further detail concerning these variables, see Brazer and McCarty $(1986,1987)$.

\section{APPENDIX B}

Notes on Variable Definition and Sample Selection

We define "Education expenditure per pupil" as Current operating expenditure for all resident pupils net of transportation expenditure, divided by resident average daily membership (ADM) in Virginia and Connecticut, and by resident enrollment in New Jersey. We constructed this variable using a variety of sources supplied by the relevant state governments. Details are available from the authors on request.

We have omitted some districts from our sample in each state. Districts were omitted because they fell below our cut-off level of 3000 in district population, because of missing data, or because schools, particularly in Connecticut, are shared among otherwise politically separate communities. Our sample districts contain $86 \%$ of statewide enrollment in Connecticut, $81 \%$ in New Jersey, and $94 \%$ in Virginia. 